Research Article

\title{
Antiulcer activity of aqueous and ethanolic extracts of Ocimum sanctum leaves in albino rats
}

\author{
Sowmya Kaniganti ${ }^{1}$, Das MC $^{2}$, Ramesh Bannaravuri ${ }^{3}$
}

\begin{abstract}
${ }^{1}$ Department of Pharmacology, Dr. Pinnamaneni Siddhartha Institute of Medical Sciences, Vijayawada, Andhra Pradesh, India

${ }^{2}$ Department of Pharmacology, NRI Medical College,

Mangalagiri, Andhra Pradesh, India

${ }^{3}$ Department of Pharmacology GIMSR, GITAM University, Vishakhapatnam, Andhra Pradesh, India
\end{abstract}

Received: 20 April 2016

Revised: 08 June 2016

Accepted: 11 June 2016

*Correspondence to:

Dr. Sowmya Kaniganti, Email: sowmya.kaniganti@ gmail.com

Copyright: (C) the author(s), publisher and licensee Medip Academy. This is an openaccess article distributed under the terms of the Creative Commons Attribution NonCommercial License, which permits unrestricted noncommercial use, distribution, and reproduction in any medium, provided the original work is properly cited.

\begin{abstract}
Background: Peptic ulcer is one of the most common gastrointestinal disorders and a major cause of morbidity. The incidence and prevalence of peptic ulcer has been increasing worldwide. Persisting peptic ulcer leads to complications like gastrointestinal bleeding, gastric perforation and pyloric obstruction. The complications further increase the morbidity and mortality. The objectives of this study were to evaluate the antiulcer activity of aqueous and ethanolic extracts of Ocimum sanctum leaves in albino rats.

Methods: 48 apparently healthy wistar albino rats of either sex weighing about 150-200 grams were divided randomly into 12 groups $(n=4)$. All the drugs were given as pre-treatment, per oral daily for 3 days. Test drugs, aqueous leaf extract $(100 \mathrm{mg} / \mathrm{kg}, 200 \mathrm{mg} / \mathrm{kg})$ and ethanolic leaf extract $(50 \mathrm{mg} / \mathrm{kg}, 100 \mathrm{mg} / \mathrm{kg})$ in $1 \%$ carboxymethylcellulose (CMC) were administered. Pyloric ligation and cold restrain stress were used as experimental models in the study. Parameters like free acid, gastric volume and ulcer index were observed.

Results: All the test drugs significantly reduced the free acid, gastric volume and ulcer index in pyloric ligation model. $100 \mathrm{mg} / \mathrm{kg}$ of aqueous leaf extract failed to decrease the ulcer index in cold restrain stress, but other doses of test drugs reduced the ulcer index.

Conclusions: Both the doses of aqueous and ethanolic extracts of Ocimum sanctum leaves exhibited significant antiulcer activity in pyloric ligation model, whereas only $200 \mathrm{mg} / \mathrm{kg}$ of aqueous leaf extract was effective in cold restrain stress model.
\end{abstract}

Keywords: Pyloric ligation, Cold restrains stress, CMC, Ranitidine, Ocimum sanctum leaves extracts

\section{INTRODUCTION}

Peptic ulcer disease (PUD) is one of the most prevalent gastrointestinal disorders affecting all age groups worldwide. An ulcer is defined as "disruption of the mucosal integrity of the stomach and/or duodenum leading to a local defect or excavation due to active inflammation". Various environmental factors like culture, religion and ethnicity have an important bearing on the occurrence, pathogenesis and treatment of peptic ulcer disease in different populations. The prevalence of peptic ulcer in particular is more in low socio-economic groups and more common in the developing countries.

A random population based study in a general adult population, found a point prevalence of $4 \%$ for PUD and 
that the persons with ulcer frequently show atypical symptoms. In India, PUD is common and the Indian Pharmaceutical Industries share 6.2 billion rupees and occupy $4.3 \%$ of the market share in consuming antacids and other antiulcer drugs. ${ }^{2}$ The estimated deaths due to peptic ulcer disease in India are about 15,000 every year. The prevalence of peptic ulcer is more in southern than in northern India. Peptic ulcer disease involves both gastric and duodenal ulcers and can occur in any portion of the gastrointestinal tract but most common in the first part of duodenum and lesser curvature of the stomach. The clinical presentation of peptic ulcer is variable. Most common symptom of peptic ulcer is abdominal discomfort. Other symptoms include epigastric burning, poor appetite, weight loss, anemia, bloating, nausea and vomiting. In patients with advanced stage, the symptoms are sharp, persistent and sudden accompanied by stomach pain, melena and hematemesis. Some patients are asymptomatic until life threatening complications like haemorrhage, perforation and stricture develop. ${ }^{3}$ Duodenal ulcers are more common than gastric ulcers but sometimes symptoms are indistinguishable.

Peptic ulcer is a multi-factorial disease with imbalance of offensive and defensive factors. The etiopathogenesis of peptic ulcer has changed from Schwartz's dictum "No acid-no ulcer" to "no mucosal damage-no ulcer" and recently to "no helicobacter pylori-no ulcer". Peptic ulcer can occur even with regurgitation of bile due to incompetent pyloric sphincter or mucosal disruption due to alcohol. Ayurveda has been practiced in India for centuries. The attention and interest in the use of traditional medicine has increased globally. According to WHO traditional medicine strategy 2002-2005 document, the use of ayurveda and medicinal plants helps to meet the primary health care needs of $65 \%$ of Indians. WHO and ICMR are encouraging wide spread researches on herbal drugs.

Although different treatment modalities are available for the prevention and treatment of peptic ulcer, side effects and high recurrence rates demand search for potent and less toxic anti-ulcer drugs. Plant extracts are the most attractive source since long time and a large number of plants have been shown to have promising anti-ulcer effects. Further the plant extracts have advantages like safety, economic, effective and easy availability. Ocimum sanctum popularly known as 'Tulasi' in Hindi and 'Holybasil' in English is an herbaceous plant. Various extracts of different parts of the plant have been used for medicinal purposes.

In ayurveda, Tulasi has been well documented for its therapeutic potentials like anti asthmatic, anti-diabetic, anti-oxidant effect. ${ }^{4}$ The antiulcer effect of various extracts of leaves and essential oil of Ocimum sanctum has been documented. Aqueous and alcoholic leaf extracts have been reported to have antiulcer activity. ${ }^{5-7}$ With these backgrounds, the present study was undertaken to study the antiulcer effect of aqueous and ethanolic extracts of Ocimum sanctum leaves.

\section{METHODS}

The study was conducted at research laboratory of department of pharmacology, NRI Medical College and General Hospital, Chinakakani, Andhra Pradesh, India.

48 Wistar albino rats were divided into 12 groups using computer generated random numbers. All the animals were maintained in a well-ventilated animal house with 12 hour light and dark cycle.

Ranitidine powder was obtained from GlaxoSmithline pharmaceuticals. Aqueous and alcoholic extracts of Ocimum sanctum leaves were obtained from Laila Pharmaceuticals, Vijayawada.

Table 1: Plan of study.

\begin{tabular}{|c|c|c|}
\hline Group & Treatment & Method \\
\hline 1 & $0.5 \mathrm{ml} \mathrm{1 \%} \mathrm{CMC}$ & pyloric ligation \\
\hline 2 & Ranitidine $10 \mathrm{mg} / \mathrm{kg}$ & pyloric ligation \\
\hline 3 & $\begin{array}{l}\text { Aqueous extract of } \\
\text { Ocimum sanctum leaves } \\
100 \mathrm{mg} / \mathrm{kg}\end{array}$ & pyloric ligation \\
\hline 4 & $\begin{array}{l}\text { Ethanolic extract of } \\
\text { Ocimum sanctum leaves } \\
50 \mathrm{mg} / \mathrm{kg}\end{array}$ & pyloric ligation \\
\hline 5 & $\begin{array}{l}\text { Aqueous extract of } \\
\text { Ocimum sanctum leaves } \\
200 \mathrm{mg} / \mathrm{kg}\end{array}$ & pyloric ligation \\
\hline 6 & $\begin{array}{l}\text { Ethanolic extract of } \\
\text { Ocimum sanctum leaves } \\
100 \mathrm{mg} / \mathrm{kg}\end{array}$ & pyloric ligation \\
\hline 7 & $0.5 \mathrm{ml} \mathrm{1 \%} \mathrm{CMC}$ & $\begin{array}{l}\text { cold restrain } \\
\text { stress }\end{array}$ \\
\hline 8 & Ranitidine $10 \mathrm{mg} / \mathrm{kg}$ & $\begin{array}{l}\text { cold restrain } \\
\text { stress }\end{array}$ \\
\hline 9 & $\begin{array}{l}\text { Aqueous extract of } \\
\text { Ocimum sanctum leaves } \\
100 \mathrm{mg} / \mathrm{kg}\end{array}$ & $\begin{array}{l}\text { cold restrain } \\
\text { stress }\end{array}$ \\
\hline 10 & $\begin{array}{l}\text { Ethanolic extract of } \\
\text { Ocimum sanctum leaves } \\
50 \mathrm{mg} / \mathrm{kg}\end{array}$ & $\begin{array}{l}\text { cold restrain } \\
\text { stress }\end{array}$ \\
\hline 11 & $\begin{array}{l}\text { Aqueous extract of } \\
\text { Ocimum sanctum leaves } \\
200 \mathrm{mg} / \mathrm{kg}\end{array}$ & $\begin{array}{l}\text { cold restrain } \\
\text { stress }\end{array}$ \\
\hline 12 & $\begin{array}{l}\text { Ethanolic extract of } \\
\text { Ocimum sanctum leaves } \\
100 \mathrm{mg} / \mathrm{kg}\end{array}$ & $\begin{array}{l}\text { cold restrain } \\
\text { stress }\end{array}$ \\
\hline
\end{tabular}

Pyloric ligation model of this study was 24 wistar albino rats of group1-6 were used. Test and standard drugs were administered to respective groups orally once daily for 3 days. ${ }^{8-10}$ On day 2 , the animals were fasted overnight. On 
day 3, 1 hour after drug administration, abdomen was opened under light ether anaesthesia by a midline incision; pyloric end of the stomach was identified and ligated with silk sutures. Care was taken not to damage the blood supply. Stomach was carefully placed inside abdominal cavity and the abdominal wall was closed with interrupted sutures. The animal was placed in a cage. There was no access to food and water for a period of 6 hours. ${ }^{11-13}$ At the end of 6th hours, the animals were sacrificed by cervical dislocation, abdomen was opened, stomach was clamped on both ends and isolated. The gastric contents were collected, centrifuged and parameters like volume of gastric contents, free acidity were estimated. The stomach was cut along the greater curvature, the edges of the stomach fixed to a myoboard and ulcer scoring was done with the help of a $10 \mathrm{X}$ magnifying lens.

\section{Parameters}

\section{Volume of gastric content}

Gastric contents collected and the volume was measured and noted.

\section{Estimation of free acid ${ }^{14-16}$}

The gastric contents were collected in test tubes and centrifuged at $1000 \mathrm{rpm}$ for about 10 minutes. $1 \mathrm{ml}$ of supernatant, diluted with $9 \mathrm{ml}$ distilled water was titrated with $\mathrm{N} / 10 \mathrm{NaOH}$ with 1 drop of Topfer's reagent as indicator. Titration was done till the pink colour changed to yellow. This volume of $\mathrm{N} / 10 \mathrm{NaOH}$ was noted, represents free acidity. Free acidity represents the amount of gastric $\mathrm{HCl}$ present in the gastric content whereas Total acidity is a combination of $\mathrm{HCl}$ and weak acids like protein, acid phosphate and organic acids like lactic acid which are produced by digestion and fermentation in the stomach. To express the value as $\mathrm{mEq} / \mathrm{Lt}$, the titre value is multiplied by 10 .

\section{Estimation of ulcer index}

The animals were sacrificed by cervical dislocation, abdominal wall was opened, stomach was dissected out carefully, opened along the greater curvature, the edges fixed to the myoboard and with the help of magnifying lens, ulcer scoring was done for individual ulcers and ulcer index was calculated for the group.

\section{Ulcer scoring was done as per the following score st,18 $^{17}$}

- 0 -Normal mucosa

- 1- 0.5-red colorations/petechial haemorrhage

- 2-1- spot ulcers

- 3-1.5-hemorrhagic streaks

- 4- 2- ulcers between $3 \mathrm{~mm}-5 \mathrm{~mm}$,
- 5- 2.5-ulcers $>5 \mathrm{~mm}$

Ulcer index was calculated using formula ${ }^{19,20}$

$\mathrm{UI}=\mathrm{UN}+\mathrm{US}+\mathrm{UP} \times 10-1$

UN - Average number of ulcers per animal,

US - Average of severity scores,

UP - Percentage of animals with ulcers in that group.

Cold-restrain stress model ${ }^{21,22}$

24 wistar albino rats of group 7-12 groups were used. Test and standard drugs were administered to respective groups orally, once daily for 3 days $8-10$. On day 2 , the animals were fasted overnight. On day 3, 1 hour after drug administration, the animals were completely restrained in wire mesh and placed in the refrigerator at $4^{0} \mathrm{C}$, for about 4 hours. ${ }^{23}$ The temperature $40 \mathrm{C}$ was constantly monitored by digital thermometer. At the end of 4 hours, the animals were sacrificed by cervical dislocation. Abdomen was opened up by midline incision. Pyloric and cardiac ends of the stomach were identified and ligated. The stomach was cut opened along the greater curvature, the contents were collected and the edges of the stomach fixed to the myoboard. Ulcer scoring was done and ulcer index calculated as above. ${ }^{16-18}$

\section{Statistical analysis}

Continuous data were analysed by one way analysis of variance (ANOVA) followed by Scheffe multiple range test to find out the significantly different groups. KruskalWallis test was used for discrete data. The level of significance was $5 \%$ ( $\mathrm{p} \leq 0.05$ was taken as significant).

\section{RESULTS}

\section{Free acid}

Standard drug ranitidine and both the test drugs significantly reduced free acid than the CMC treated control group (group 1) $(\mathrm{p}<0.05)$.

\section{Gastric volume}

Standard and the test drugs significantly reduced the gastric volume in comparison to control group $(\mathrm{p}<0.05)$.

\section{Ulcer index (pyloric ligation model)}

Standard and the test drugs significantly reduced ulcer index in pyloric ligation model compared to group 1 $(\mathrm{p}<0.05)$. Reduction in ulcer index was more with Aqueous extract $200 \mathrm{mg} / \mathrm{kg}$. 
Table 2: Effect of drugs on parameters in pyloric ligation method.

\begin{tabular}{|lllll|}
\hline Group no. & Drug & Free acid (Mean+SEM) & Gastric volume (Mean+SEM) & Ulcer index (mean rank) \\
\hline $\mathbf{1}$ & CMC & $24.0 \pm 1.581$ & $9.33 \pm 0.364$ & 22.50 \\
\hline $\mathbf{2}$ & Ran 10 & $9.80 \pm 0.854^{*}$ & $2.85 \pm 0.155^{*}$ & $13.50^{*}$ \\
\hline $\mathbf{3}$ & AE 100 & $5.50 \pm 0.645^{*}$ & $3.93 \pm 1.109^{*}$ & $17.50^{*}$ \\
\hline $\mathbf{4}$ & EE 50 & $7.50 \pm 0.645^{*}$ & $5.80 \pm 0.227^{*}$ & $10.75^{*}$ \\
\hline $\mathbf{5}$ & AE 200 & $6.00 \pm 0.408^{*}$ & $3.50 \pm 0.438^{*}$ & $3.25^{*}$ \\
\hline $\mathbf{6}$ & EE 100 & $6.50 \pm 1.041^{*}$ & $3.78 \pm 1.133^{*}$ & $7.63^{*}$ \\
\hline
\end{tabular}

$\mathrm{CMC}=$ carboxymethylcellulose; Ran $10=$ Rantidine $10 \mathrm{mg} / \mathrm{kg}, \mathrm{AE} 100=$ Aqueous extract of Ocimum sanctum leaves $100 \mathrm{mg} / \mathrm{kg}$, AE 200 = Aqueous extract of Ocimum sanctum leaves $200 \mathrm{mg} / \mathrm{kg}$; EE $50=$ Ethanolic extract of Ocimum sanctum leaves $50 \mathrm{mg} / \mathrm{kg}$ , EE $100=$ Ethanolic extract of Ocimum sanctum leaves $100 \mathrm{mg} / \mathrm{kg} .{ }^{*}=>\mathrm{p}<0.05$ as compared to control.

Table 3: Effect of drugs on ulcer index in cold restrains stress method.

\begin{tabular}{|lll|}
\hline Group no. & Drug & Ulcer index (mean rank) \\
\hline 7 & CMC & 22.50 \\
\hline 8 & Ran 10 & $2.50^{*}$ \\
\hline 9 & AE 100 & 18.50 \\
\hline 10 & EE 50 & $14.50^{*}$ \\
\hline 11 & AE 200 & $10.50^{*}$ \\
\hline 12 & EE 100 & $6.50^{*}$ \\
\hline
\end{tabular}

$\mathrm{CMC}=$ carboxymethylcellulose; Ran $10=$ Rantidine 10 $\mathrm{mg} / \mathrm{kg}, \mathrm{AE} 100=$ Aqueous extract of Ocimum sanctum leaves $100 \mathrm{mg} / \mathrm{kg}$, AE $200=$ Aqueous extract of Ocimum sanctum leaves $200 \mathrm{mg} / \mathrm{kg}$; EE $50=$ Ethanolic extract of Ocimum sanctum leaves $50 \mathrm{mg} / \mathrm{kg}$, EE $100=$ Ethanolic extract of Ocimum sanctum leaves $100 \mathrm{mg} / \mathrm{kg}$. * $\Rightarrow$ p $<0.05$ as compared to control.

\section{Ulcer index (cold restrain model)}

Ethanolic leaf extract $50 \mathrm{mg} / \mathrm{kg}, 100 \mathrm{mg} / \mathrm{kg}$ and aqueous leaf extract $200 \mathrm{mg} / \mathrm{kg}$ significantly reduced ulcer index in cold restrain model compared to CMC treated control group. Ranitidine $10 \mathrm{mg} / \mathrm{kg}$, exhibited more reduction in ulcer index. Aqueous leaf extract $100 \mathrm{mg} / \mathrm{kg}$ failed to produce reduction in ulcer index in cold restrain stress model.

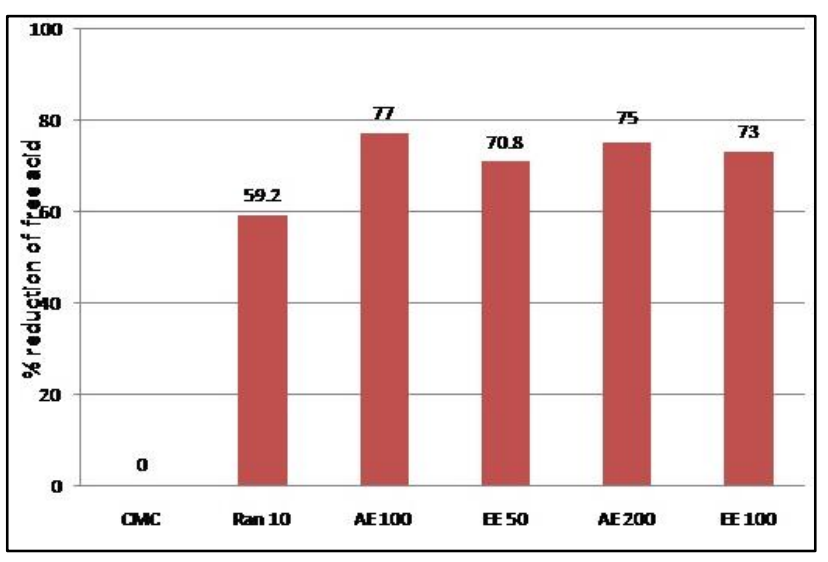

Figure 1: Effect of drugs on free acid in pyloric ligation method.
It was observed that ranitidine reduced free acid by $59.2 \%$, Aqueous leaf extracts $100 \mathrm{mg} / \mathrm{kg}$ and $200 \mathrm{mg} / \mathrm{kg}$ reduced the free acid level by $77 \%$ and $75 \%$ respectively and ethanolic leaf extracts $50 \mathrm{mg} / \mathrm{kg}$ and $100 \mathrm{mg} / \mathrm{kg}$ reduced the free acid level by $70.8 \%$ and $73 \%$ respectively. The test drugs viz. aqueous leaf extracts in both the doses and ethanolic leaf extracts in both the doses; exhibited more reduction in free acid compared to ranitidine in pyloric ligation model.

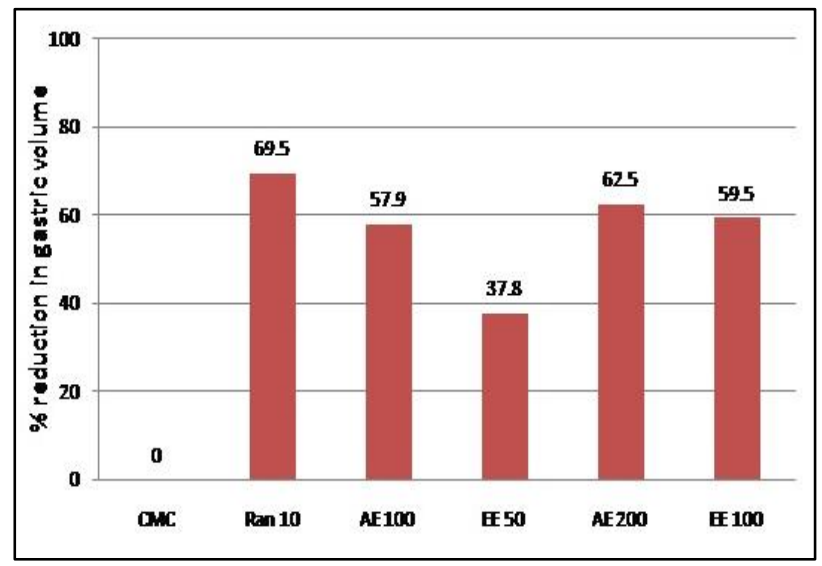

Figure 2: Effect of drugs on gastric volume in pyloric ligation model.

The gastric volume increased after pyloric ligation. Ranitidine reduced the gastric volume by $69.5 \%$, aqueous leaf extracts $100 \mathrm{mg} / \mathrm{kg}$ and $200 \mathrm{mg} / \mathrm{kg}$ by $57.9 \%$ and $62.5 \%$ respectively, ethanolic leaf extracts $50 \mathrm{mg} / \mathrm{kg}$ and $100 \mathrm{mg} / \mathrm{kg}$, reduced by $37.8 \%$ and $59.5 \%$ respectively. All doses of test drugs studied exhibited identical effect to that of ranitidine.

Ulcer index is a measure of severity of gastric ulceration. Ranitidine reduced the ulcer index by $32.9 \%$. Aqueous leaf extracts $100 \mathrm{mg} / \mathrm{kg}$ and $200 \mathrm{mg} / \mathrm{kg}$, reduced ulcer index by $21.7 \%$ and $46.7 \%$ respectively. Ethanolic leaf extracts $50 \mathrm{mg} / \mathrm{kg}$ and $100 \mathrm{mg} / \mathrm{kg}$, reduced ulcer index by $33.3 \%$ and $40.4 \%$ respectively. $100 \mathrm{mg} / \mathrm{kg}$ of ethanolic leaf extract and $200 \mathrm{mg} / \mathrm{kg}$ aqueous leaf extract exhibited more reduction of the ulcer index than ranitidine. 50 
$\mathrm{mg} / \mathrm{kg}$ of ethanolic leaf extract produced effect identical to that of ranitidine.

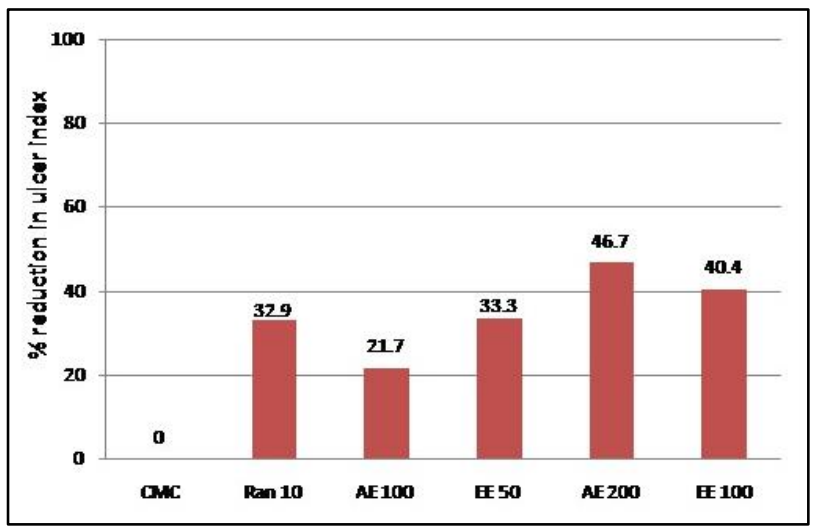

Figure 3: Effect of drugs on ulcer index in pyloric ligation model.

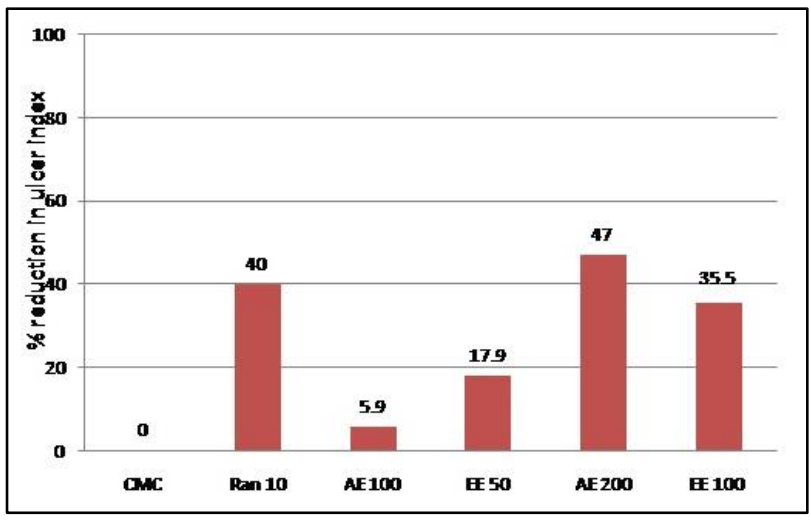

Figure 4: Effect of drugs on ulcer index in cold stress restrain model.

Ranitidine reduced the ulcer index by $40 \%$. Aqueous leaf extract $200 \mathrm{mg} / \mathrm{kg}$, ethanolic leaf extracts $50 \mathrm{mg} / \mathrm{kg}$ and $100 \mathrm{mg} / \mathrm{kg}$, reduced the ulcer index by $47 \%, 35.5 \%$ and $17.9 \%$ respectively. Aqueous leaf extract $100 \mathrm{mg} / \mathrm{kg}$ failed to reduce ulcer index in cold restrain stress model. Aqueous leaf extract $200 \mathrm{mg} / \mathrm{kg}$ exhibited better protection than ranitidine.

\section{DISCUSSION}

Ranitidine is a potent and selective $\mathrm{H} 2$ receptor antagonist. $^{24}$ It can be administered by both oral and parenteral routes. Studies have shown that ranitidine 10 $\mathrm{mg} / \mathrm{kg}$ was effective in reducing the gastric acid secretion by $90-95 \% .^{25}$ So it has been used as a standard drug. Pyloric ligation for 6 hours resulted in accumulation of gastric secretion resulting in increased volume and titratable acid. The accumulated acid may be responsible for gastric ulceration. Gastric hydrochloric acid $(\mathrm{HCl})$ accounts for the free acidity of gastric juice. The role of hydrochloric acid in the pathogenesis of gastric ulcer is well established. The volume of gastric secretion is also an important factor in the formation of ulcer. In pyloric ligation model, acid accumulates leading to ulcer formation.

The test drugs viz. aqueous leaf extracts in both the doses and ethanolic leaf extracts in both the doses; significantly reduced free acid and gastric volume in pyloric ligation model. Decrease in free acid may be responsible for antiulcer effect similar to that of ranitidine.

Pyloric ligation induces ulcers by auto digestion of the gastric mucosa and breakdown of the gastric mucosal barrier. Ulcer index is a measure of severity of gastric ulceration. Acid output is closely associated with the occurrence of stress-induced lesions. Standard and test drugs in all doses studied reduced the ulcer index. These results are similar to the observations of Ghangale et al and Harshal et al.,7

Ranitidine reduced the ulcer index by $40 \%$ in cold restrain stress. Although aqueous leaf extract $100 \mathrm{mg} / \mathrm{kg}$ failed to reduce ulcer index in cold restrain stress model, aqueous leaf extract $200 \mathrm{mg} / \mathrm{kg}$, ethanolic leaf extracts $50 \mathrm{mg} / \mathrm{kg}$ and $100 \mathrm{mg} / \mathrm{kg}$ produced significant reduction in ulcer index similar to that of Ranitidine. The observations are similar to that of Bharat et al. ${ }^{6}$

\section{CONCLUSION}

Aqueous leaf extracts $(100 \mathrm{mg} / \mathrm{kg}$ and $200 \mathrm{mg} / \mathrm{kg})$ and ethanolic leaf extracts $(50 \mathrm{mg} / \mathrm{kg}$ and $100 \mathrm{mg} / \mathrm{kg})$ exhibited better protection than ranitidine in reducing free acid in pyloric ligation model. All doses of test drugs studied exhibited identical effect to that of ranitidine in reducing free acid and gastric volume. Ethanolic leaf extract 100 and $200 \mathrm{mg} / \mathrm{kg}$ aqueous leaf extract exhibited better protection compared to ranitidine in reducing the ulcer index in pyloric ligation model. $50 \mathrm{mg} / \mathrm{kg}$ of ethanolic leaf extract produced effect identical to ranitidine. Aqueous leaf extract $200 \mathrm{mg} / \mathrm{kg}$ exhibited better protection compared to ranitidine in reducing the ulcer index but aqueous leaf extract $100 \mathrm{mg} / \mathrm{kg}$ was ineffective in cold restrain stress model.

\section{Funding: No funding sources}

Conflict of interest: None declared

Ethical approval: The study was approved by the Institutional Ethics Committee

\section{REFERENCES}

1. Alvin CP. Diabetes mellitus. In: Anthony SF, Dennis LK, Dan LL, Eugene B, Stephen LH, Jameson JL, Joseph L editors. Harrison's principles of internal medicine. $17^{\text {th }}$ ed. United States of America: Mc graw hill companies pvt ltd; 2008:2294.

2. Shagufta N, Javed Ahmed K, Ghufran A. Some experimentally proved herbs in peptic ulcer disease. Int J Pharm Sci Res. 2012;3(8):2387-92.

3. Fu We W, Ming ST, Guang YM, Hung YC, Hsien $\mathrm{CY}$, Lung $\mathrm{Ch} \mathrm{C}$, et al. Prevalence and risk factors of 
asymptomatic peptic ulcer disease in Taiwan. World J Gastroenterol. 2011;17(9):1199-203.

4. Swetha G, Pramod KM, Surender S, Sharma KK, Rimi S. Antidiabetic antihypercholesterolaemic and antioxidant effect of ocimum sanctum linn seed oil. Ind J Exp Bio. 2006;44:300-4.

5. Ghangale GR, Tushar M, Jadhav ND. Evaluation of antiulcer activity of ocimum sanctum in rats. Veterinary world. 2009;2(12):465-6.

6. Bharat BM, Das MC, Subas CD, Nagoji KEV. Antiulcer activity of aqueous and ethanolic leaf extracts of Krishna tulasi (ocimum sanctum) in albino rats. Res J Pharm Bio Chem Sci. 2013;4(2):961-6.

7. Harshal F, Yaseen G, Amit V, Sagar B, Sudhakar J, Nikku Y. Evaluation of ulcer protective effects of ocimum sanctum and zingiber officinalis as herbo formulation for aspirin induced ulcerations in albino rats. Der Pharmacia Sinica. 2011;2(2):46-53.

8. Ramaswamy S, Sengottuvelu S, Sherief SH, Jaikumar S, Saravanan R, Prasad Kumar C, et al. Gastroprotective activity of ethanolic extract of trachyspermum ammi fruit. Int $\mathrm{J}$ Pharm Biosci. 2010;1(1):1-15.

9. Patchareewan P, Jintanaporn W, Orapin P, Wichittra T, Bunkerd K. Antigastric ulcer effect of turmeric in rats. Srinagarind Med J. 2000;15(4):250-4.

10. Atta AH, Soad MN, Samar MM. Anti ulcerogenic effect of some plant extracts. Natural product radiance. 2005;4(4):258-63.

11. Sumalatha G, Bahlul ZA, Baburao C, Mukkanti K. Anti ulcerogenic and ulcer healing studies of aqueous extract of peurparia tuberosa leaves on rats. Int $\mathrm{J}$ Pharm Bio Sci. 2010;1(4):657-61.

12. Manish AR, Sunita MJ. Gastroprotective effect of benincasa hispida fruit extract. Ind $\mathrm{J}$ Pharmacol. 2008;40(6):271-5.

13. Pankaj K, Sunil S, Suman, Suresh K. Antiulcer effect of methanolic extract of tamarindus indica seeds in different experiment models. J Pharm Bioallied Sci. 2011;3(2):236-41.

14. Jaikumar S, Ramaswamy S, Arokam BR, Mohan T, Gnanavel M. Antiulcer activity of methanolic extract of jatropha curcas linn on aspirin induced gastric lesions in wistar strain rats. Res J Pharm Bio Chem Sci. 2010;1(4):886-97.
15. Ponnudurai K, Prabhu K, Jebasingh D, Prabu D. Evaluation of antiulcer activity of ethanolic extract of abutilon indicum linn sweet leaves. Der Pharmacia Sinicia. 2011;2(4):148-58.

16. Yogendr B, Kalpana P, Mohan Singh MR, Sunil J, Sampada U. Antiulcer activity of melia azedarach linn in aspirin induced and pylorus ligated rats. J Pharm Res. 2009;2(9):1456-9.

17. Anurag K, Uma Shankar S, Rao Ch V. Experimental evaluation of ficus racemosa linn fruits extract on gastric ulceration. Int $\mathrm{J}$ Pharm Sci Rev Res. 2010;4(3):89-92.

18. Vidya S, Ramesh A, Alekhya N, Lohith I. Antiulcer activity of Eugenia jambolana leaves against ethanol induced gastric ulcers in albino rats. Int $\mathbf{J}$ Pharm Res Dev. 2011;3(5):106-12.

19. Muhammed Ashraf VK, Thamotharan G, Sengottuvelu S, Sherief HS, Sivakumar T. Evaluation of antiulcer activity of ficus pumila linn leaf extract in albino rats. Global J Res Med Plants Indigen Med. 2012;1(8):340-51.

20. Nilesh M, Dinesh S, Dhirendra S. Evaluation of antiulcer potential of leaves of jasminum grandiflorum. Int J Ph Sci. 2009;1(2):247-9.

21. Mohammed Safwan AK, Syed Ahmed H, Abdul Manam MJ, Zainul AZ, Mohib K. Antiulcer activity of ficus relgiosa stem bark ethanolic extract in rats. $\mathbf{J}$ Med Plants Res. 2011;5(3):354-9.

22. Thamotharan G, Sekar G, Ganesh T, Sen S, Raja C, Senthil Kumar N. Antiulcerogenic effects of lantana camara linn leaves on in vivo test models in rats. Asian J Pharm Clin Res. 2010;3(3):57-60.

23. Samuel AO, Neetu S, Samuel BO, Vaibhav M, Gautam P. Antiulcer and antioxidant activities of hedranthera barteri with possible involvement of $\mathrm{H}+$ $\mathrm{K}+$ ATPase inhibitiory activity. Ind $\mathrm{J}$ Med Res. 2010;132:442-9.

24. Kenneth R, McQuaid MD. Basic and clinical pharmacology. $11^{\text {th }}$ ed. Tata McGraw Hill Education Private Limited; 2009:1069-71.

25. Deshmukh VN, Nehete JY, Shewale VV, Raghav NA, Gawande VT. Gastric antiulcer activity of achyranthes aspera linn roots in pylorus ligated rats. Global J Pharmacol. 2011;5(3):143-6.

Cite this article as: Kaniganti S, Das MC, Bannaravuri R. Antiulcer activity of aqueous and ethanolic extracts of Ocimum sanctum leaves in albino rats. Int $\mathrm{J}$ Basic Clin Pharmacol 2016;5:1353-8. 